\title{
Opitutus terrae gen. nov., sp. nov., to accommodate novel strains of the division 'Verrucomicrobia' isolated from rice paddy soil
}

Max-Planck-Institut für terrestrische Mikrobiologie, D-35043 Marburg, Germany

\author{
Kuk-Jeong Chin, Werner Liesack and Peter H. Janssen†
}

\begin{abstract}
Author for correspondence: Peter H. Janssen. Tel: +6138344 5706. Fax: +61393471540. e-mail: pjanssen@unimelb.edu.au
\end{abstract}

\begin{abstract}
Three strains of obligately anaerobic bacteria were isolated from rice paddy soil microcosms. Comparative analysis of the 16S rRNA genes showed that these novel isolates have identical gene sequences and are members of the division 'Verrucomicrobia'. The novel strains are phenotypically and phylogenetically distinct from species described previously. One strain, PB90-1 ${ }^{\top}$, was characterized in more detail. The cells are cocci and are motile by means of a flagellum. Catalase and oxidase activities are absent. Growthsupporting substrates include mono-, di- and polysaccharides, while alcohols, amino acids and organic acids do not support growth. Propionate and acetate are the major end-products of fermentation. Nitrate is reduced to nitrite, but other external electron acceptors are not utilized. The $\mathrm{G}+\mathrm{C}$ content of the genomic DNA is $74 \mathrm{~mol} \%$. This strain represents a taxon that has not yet been formally recognized, for which the name Opitutus terrae gen. nov., sp. nov. is proposed. The type strain is PB90-1' (= DSM 11246').
\end{abstract}

Keywords: Opitutus terrae, 'Verrucomicrobia', 16S rRNA gene, anaerobe

\section{INTRODUCTION}

Molecular ecological studies, based on the recovery of 16S rRNA gene sequences from many different habitats, have revealed a great diversity of bacterial groups encompassing many as-yet uncultivated organisms, often only distantly related to currently known isolates. One of the phyla or divisions of bacterial descent with very few cultivated representatives, but for which $16 \mathrm{~S}$ rRNA gene sequences reveal a much wider phylogenetic diversity than that known from cultivation studies, is the division 'Verrucomicrobia' (Hedlund et al., 1997; Hugenholtz et al., 1998). We have recently reported the detection of members of this lineage in a library of cloned $16 \mathrm{~S}$ rRNA genes from anoxic rice paddy soil (Hengstmann et al., 1999) and reported the isolation of very close relatives of these molecularly detected organisms in parallel cultivation studies from the same soil sample (Chin et al., 1999). Our previous investigations

\footnotetext{
†Present address: Department of Microbiology and Immunology, University of Melbourne, Victoria 3010, Australia.

The GenBank/EMBL/DDBJ accession number for the 16S rRNA gene sequence of strain PB90-1 ${ }^{\top}$ is AJ229235.
}

(Hengstmann et al., 1999; Chin et al., 1999) suggested that the novel isolates, strains PB90-1 ${ }^{\mathrm{T}}$, PB90-3 and ACB90, are phylogenetically distinct from currently described species of bacteria. We have characterized one of these strains further and describe it as the type strain of a new species and genus, Opitutus terrae gen. nov., sp. nov.

\section{METHODS}

Cultivation and characterization. Strain PB90-1 ${ }^{\mathrm{T}}$ (= DSM $11246^{\mathrm{T}}$ ) was isolated from rice paddy soil microcosms in an earlier study (Chin et al., 1999) and was grown in sulfidereduced, bicarbonate-buffered mineral medium SM supplemented with vitamins as described by Chin et al. (1999). Growth substrates and other supplements were prepared as neutralized (with $\mathrm{NaOH}$ or $\mathrm{HCl}$, as required), $0 \cdot 2-2 \mathrm{M}$ or $5 \%(\mathrm{w} / \mathrm{v})$ stock solutions and were sterilized by autoclaving or, in the case of heat-labile compounds and sugars, by filtration (pore size $0 \cdot 2 \mu \mathrm{m}$ ). Substrates were added to sterile media just before inoculation. L-Isomers of organic and amino acids and D-isomers of sugars were used. Amorphous cellulose and pectin were prepared as described previously (Janssen et al., 1997). Unless noted otherwise, cultures were grown at $\mathrm{pH} 7.2$ and at $30^{\circ} \mathrm{C}$, in the dark, with $4 \mathrm{mM}$ glucose as the growth substrate.

The methods used for checking culture purity and for phenotypic characterization have been described previously 
(Janssen et al., 1997; Chin et al., 1998, 1999). The G+C content of the genomic DNA was determined by HPLC (Janssen et al., 1996).

Electron microscopy Formvar-coated copper grids were floated on a drop of bacterial culture to allow cells to adhere. The grids were then floated on a drop of $10 \mathrm{mM}$ potassium phosphate buffer $(\mathrm{pH} 7 \cdot 4)$ containing $4 \%(\mathrm{w} / \mathrm{v})$ paraformaldehyde (dissolved just prior to use) to fix the cells and then 'washed' by floating on a drop of sterile water. The cells were then stained by floating the grid on a drop of $1 \%(\mathrm{w} / \mathrm{v})$ uranyl acetate ( $\mathrm{pH} 4.0)$ and then washed again on water. The cells were examined with a CM120 BioTWIN transmission electron microscope (Philips).

Comparative 16S rRNA gene sequence analysis. The phylogenetic position of strain PB90-1 ${ }^{\mathrm{T}}$ in relation to representative members of the division 'Verrucomicrobia' was deduced from evolutionary distances (Jukes \& Cantor, 1969) and a neighbour-joining algorithm (Saitou \& Nei, 1987), as described previously (Hengstmann et al., 1999), implemented in the ARB program package (developed by $\mathrm{O}$. Strunk and W. Ludwig, Technische Universität München; http://www.mikro.biologie.tu-muenchen.de/pub/ARB/). All reference sequences used for the treeing analysis had at least 1400 unambiguously determined nucleotide sequence positions. The only exceptions were the cloned 16S rRNA gene sequences RB14 and RB24 from uncultured bacteria, for which 928 and 984 nucleotide sequence positions, respectively, were available. The dendrogram was constructed on the basis of a consideration of 1281 alignment positions that contained identical nucleotides in at least $50 \%$ of the $16 \mathrm{~S}$ rRNA gene sequences compared. The evolutionary distances between pairs of sequences were calculated by taking into account only those alignment positions at which both sequences had an unambiguously determined nucleotide.

\section{RESULTS AND DISCUSSION}

\section{Morphological and cytological characteristics}

Cells of strain PB90-1 ${ }^{\mathrm{T}}$ were cocci, $0 \cdot 4-0.6 \mu \mathrm{m}$ in diameter and motile by means of a flagellum (Fig. 1). Diplococci were commonly observed, but only one cell of these ever had a flagellum. Sometimes, short chains of three or four cells were observed, which had the

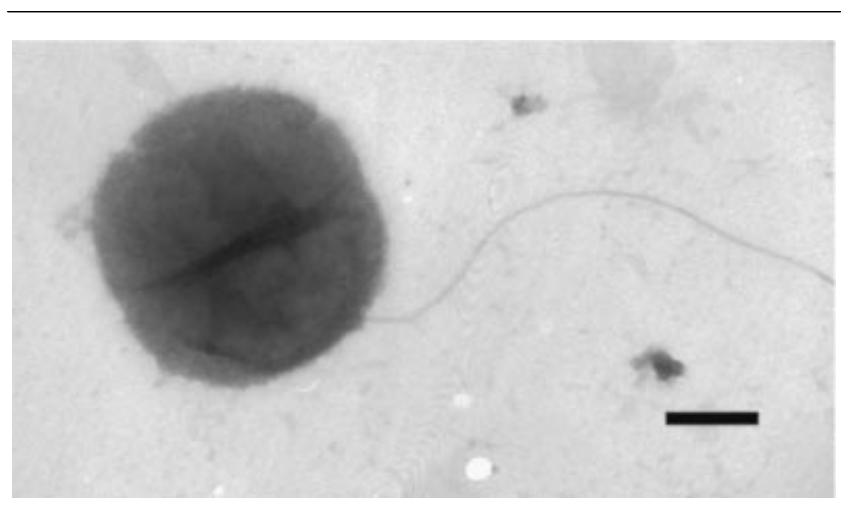

Fig. 1. Electron micrograph of a negatively stained preparation of strain PB90-1 ${ }^{\top}$, showing a dividing cell with a single flagellum. Bar, $200 \mathrm{~nm}$. appearance of short rods when viewed with the phasecontrast microscope.

Cells of strain PB90-1 ${ }^{\mathrm{T}}$ stained Gram-negative. The aminopeptidase reaction and $\mathrm{KOH}$ test were both positive. No spores were observed in fresh cultures, in cultures grown with $50 \mathrm{mM}$ glucose or in cultures grown with $4 \mathrm{mM}$ glucose with increased concentrations of $\mathrm{CaCl}_{2} \cdot 2 \mathrm{H}_{2} \mathrm{O}\left(0 \cdot 3 \mathrm{~g} \mathrm{l}^{-1}\right), \mathrm{MnCl}_{2} \cdot 4 \mathrm{H}_{2} \mathrm{O}$ $\left(50 \mathrm{mg} \mathrm{l}^{-1}\right)$ and thiamine chloride hydrochloride $\left(30 \mathrm{mg} \mathrm{l}^{-1}\right)$ and supplemented with $10 \%(\mathrm{v} / \mathrm{v})$ soil extract. The colonies in agar deeps were unpigmented and granular in appearance.

The $\mathrm{G}+\mathrm{C}$ content of the genomic DNA of strain PB $90-1^{\mathrm{T}}$ was $73 \cdot 7 \pm 0 \cdot 3 \mathrm{~mol} \%($ mean $\pm \mathrm{SD} ; n=3)$.

\section{Nutritional characteristics}

Mono-, di- and polysaccharides supported growth of strain PB90-1 ${ }^{\mathrm{T}}$. Growth was observed with glucose, fructose, galactose, mannose, galacturonic acid, mannitol, arabinose (all tested at $4 \mathrm{mM}$ ), cellobiose, maltose, sucrose, lactose, melibiose (all tested at $2 \mathrm{mM}$ ), xylan, pectin and starch (all tested at $0 \cdot 1 \%$, $\mathrm{w} / \mathrm{v}$ ). Those substrates tested and found not to support growth were xylose, ribose, sorbose, methyl $\alpha$-glucopyranoside (all tested at $2 \mathrm{mM}$ ), cellulose, chitin, arabinogalactan (all tested at $0 \cdot 1 \%, \mathrm{w} / \mathrm{v}$ ), pyruvate, lactate, fumarate, malate, tartrate, citrate, crotonate, glycerol (with or without $2 \mathrm{mM}$ acetate), aspartate, alanine, serine, leucine, isoleucine, glutamate, proline, lysine (all tested at $20 \mathrm{mM}$ ) and $\mathrm{H}_{2}(60 \mathrm{kPa}$ with or without $2 \mathrm{mM}$ acetate).

Propionate and acetate were the major end-products of fermentation. Smaller amounts $\left(\leqslant 0.2 \mathrm{~mol} \mathrm{~mol}^{-1}\right.$ monosaccharide or other growth substrate used) of succinate, lactate, ethanol and $\mathrm{H}_{2}$ were also formed. On pectin, methanol was also produced. Strain PB90-1 ${ }^{\mathrm{T}}$ used nitrate as an electron acceptor with glucose and the sole product of nitrate reduction was nitrite. Sulfur, sulfate, sulfite, thiosulfate and fumarate were not used as electron acceptors.

\section{Growth and biochemical properties}

Strain PB90- $1^{\mathrm{T}}$ behaved as an obligate anaerobe in oxygen-tolerance tests. No growth occurred on aerobically incubated agar plates with nutrient broth and glucose. Strain PB90-1 ${ }^{\mathrm{T}}$ was unable to grow in the upper $20 \mathrm{~mm}$ of agar deep cultures under a headspace of $\mathrm{N}_{2} / \mathrm{CO}_{2}$ to which $20 \mathrm{kPaO} \mathrm{O}_{2}$ was added.

Strain PB90- $1^{\mathrm{T}}$ was able to grow at $\mathrm{pH}$ values from $5 \cdot 5$ to $9 \cdot 0$, with maximum growth rates being achieved at $\mathrm{pH} 7 \cdot 5-8 \cdot 0$. Growth was possible at temperatures of 10 to $37^{\circ} \mathrm{C}$, but no growth occurred at 4 or $40^{\circ} \mathrm{C}$. Growth was possible in growth media supplemented with $30 \mathrm{~g} \mathrm{NaCl}^{-1}$ but not with $40 \mathrm{~g} \mathrm{NaCl}^{-1}$. 


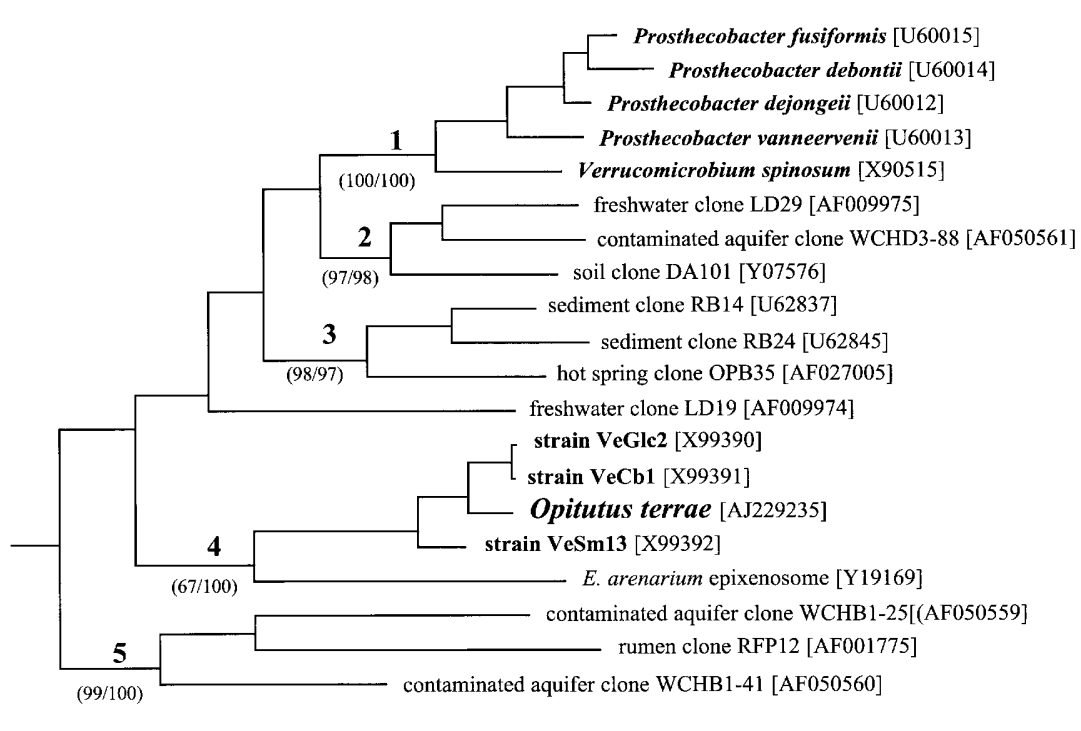

0.10
Fig. 2. Neighbour-joining dendrogram showing the phylogenetic position of strain PB90- $1^{\top}$ (Opitutus terrae) in relation to representative 16S rRNA gene sequences that encompass the currently known phylogenetic diversity of the division 'Verrucomicrobia'. Validly described species and cultivated strains are shown in bold. The habitat source is indicated before the name of cloned sequences of as-yet uncultivated organisms. EMBL/GenBank/DDBJ accession numbers are listed in parentheses. The numbers before the interior branch points indicate those five major lineages within the division 'Verrucomicrobia' for which the taxonomic level of subdivision has been proposed (Hugenholtz et al., 1998). These five major lineages were recovered in all treeing analyses with respective bootstrap values above 65 and $90 \%$ in neighbourjoining (first number under branch point) and parsimony (second number under branch point) analyses (1000 data resamplings). Scale bar, 0.10 changes per nucleotide position.
Strain PB90-1 ${ }^{\mathrm{T}}$ hydrolysed aesculin, but did not hydrolyse gelatin or urea. No catalase or oxidase activities were detected.

\section{Phylogenetic relationships}

Strains PB90-1 ${ }^{\mathrm{T}}$, PB90-3 and ACB90 have identical full-length 16S rRNA gene sequences (Hengstmann et al., 1999). Their membership of the division 'Verrucomicrobia' (Hedlund et al., 1997) has been reported previously (Hengstmann et al., 1999). The division 'Verrucomicrobia' is represented by only a few cultivated species and the majority of members of this division are known only as $16 \mathrm{~S}$ rRNA gene sequences recovered from a variety of habitats (Hedlund et al., 1997; Hugenholtz et al., 1998; Zwart et al., 1998; O'Farrell \& Janssen, 1999). The closest cultivated relatives of the novel strains are strains $\mathrm{VeCb} 1, \mathrm{VeGlc} 2$ and VeSm13 (Janssen et al., 1997; Hengstmann et al., 1999). The latter three strains share 16S rRNA gene sequence similarities with PB90- $1^{\mathrm{T}}$, PB90-3 and ACB90 of between 96 (VeCb1, VeGlc2) and 97\% (VeSm13) and thus all of these strains could be members of the same genus. The similarity values between the 16S rRNA gene sequences of strains PB90-1 ${ }^{\mathrm{T}}$, PB90-3 and ACB90 and those of members of the genera Verrucomicrobium (Schlesner, 1987) and Prosthecobacter (Staley et al., 1976; Hedlund et al., 1997), the only two named genera of the division 'Verrucomicrobia' with cultivated strains, range from 79.8 to $80.1 \%$. These rather large phylogenetic distances are the basis for the inclusion of the novel strains in the recently proposed subdivision 4 (Hugenholtz et al., 1998) of the division 'Verrucomicrobia', while members of the genera Verrucomicrobium and Prosthecobacter form a coherent cluster within subdivision 1 (Hugenholtz et al., 1998) (Fig. 2). Verrucomicrobium spinosum and
Prosthecobacter species are aerobic bacteria with rodshaped cells and their phenotypic characteristics (Staley et al., 1976; Schlesner, 1987; Hedlund et al., 1997) are quite different from those of the novel isolates. The recently described ectosymbiont of the hypotrich ciliate Euplotidium arenarium (Petroni et al., 2000) appears to be a member of subdivision 4 (Fig. 2), but it has not yet been named and is not available in pure culture. This ectosymbiont shares 16S rRNA gene sequence similarity of $83 \%$ with strains PB90-1 ${ }^{\mathrm{T}}$, PB90-3 and ACB90, while the similarity values with 16S rRNA gene sequences representative of the other subdivisions (Fig. 2) range between 74 and $78 \%$. The uncultured endosymbionts of nematodes reported recently by Vandekerckhove et al. (2000), assigned to the genus Xiphinematobacter, are members of subdivision 2 and hence are phylogenetically well separated from the three novel strains (not shown in Fig. 2).

Strains PB90-1 ${ }^{\mathrm{T}}$, PB90-3 and ACB90 are phenotypically very similar (Chin et al., 1999). All three strains have no close phylogenetic relatives that have been formally named in the taxonomic literature and are phenotypically distinct from previously described genera and species of the division 'Verrucomicrobia'. Accordingly, we designate strain PB $90-1^{\mathrm{T}}$ as the type strain of a new species in a new genus, which we name Opitutus terrae gen. nov., sp. nov. Strains PB90-3 and ACB90 appear to belong to the same species.

\section{Description of Opitutus gen. nov.}

Opitutus (O.pi.tu'tus. L. fem. n. Ops a Roman Earth and harvest goddess; L. part. adj. tutus protected; N.L. masc. n. Opitutus the one protected by Ops).

Cells are cocci, motile by means of flagella. No spores are formed. Growth-supporting substrates include 
mono-, di- and polysaccharides. Alcohols, amino acids and organic acids do not support growth. Propionate and acetate are the major end-products of fermentation. Nitrate can be reduced to nitrite. Obligately anaerobic metabolism. No catalase or oxidase activity. On the basis of comparative analysis of the 16S rRNA genes, members of this genus belong phylogenetically to subdivision 4 (sensu Hugenholtz et al., 1998) of the division 'Verrucomicrobia'. The type species is Opitutus terrae.

\section{Description of Opitutus terrae sp. nov.}

Opitutus terrae (ter'rae. L. gen. n. terrae of the earth). Cells are cocci, $0 \cdot 4-0 \cdot 6 \mu \mathrm{m}$ in diameter, motile by means of a flagellum. No spores are formed. The colonies in agar deeps are unpigmented and granular in appearance. The $\mathrm{G}+\mathrm{C}$ content of the genomic DNA of strain PB90- $1^{\mathrm{T}}$ is $74 \mathrm{~mol} \%$. The type strain grows with glucose, fructose, galactose, mannose, galacturonic acid, mannitol, arabinose, cellobiose, maltose, sucrose, lactose, melibiose, xylan, pectin and starch. Xylose, ribose, sorbose, methyl $\alpha$-glucopyranoside, cellulose, chitin, arabinogalactan, pyruvate, lactate, fumarate, malate, tartrate, citrate, crotonate, glycerol (with or without acetate), aspartate, alanine, serine, leucine, isoleucine, glutamate, proline, lysine and $\mathrm{H}_{2}$ (with or without acetate) do not support growth of the type strain. Propionate and acetate are the major end-products of fermentation. Succinate, lactate, formate, ethanol and $\mathrm{H}_{2}$ are also produced. Methanol is also formed from pectin. Nitrate is reduced to nitrite. Sulfur, sulfate, sulfite, thiosulfate and fumarate are not used as electron acceptors. Obligately anaerobic. The type strain grows at $\mathrm{pH}$ values of $5 \cdot 5$ to $9 \cdot 0$, with maximum growth rates at $\mathrm{pH} 7 \cdot 5-8 \cdot 0$. Growth of the type strain is possible at temperatures of 10 to $37^{\circ} \mathrm{C}$, but not at 4 or $40^{\circ} \mathrm{C}$. Aesculin is hydrolysed, but gelatin and urea are not. The type strain is PB90-1 ${ }^{\mathrm{T}}$ (= DSM $11246^{\mathrm{T}}$ ).

\section{ACKNOWLEDGEMENTS}

This research was supported in part by the Deutsche Forschungsgemeinschaft. K. J. C. was supported by a personal grant from the Katholischer Akademischer AusländerDienst, Germany. We thank Alexandra Schuhmann-Pidun for excellent technical assistance, Sarah Wilson for aid with the electron microscopy and Professor Dr Dr H. G. Trüper for nomenclatural advice.

\section{REFERENCES}

Chin, K.-J., Rainey, F. A., Janssen, P. H. \& Conrad, R. (1998). Methanogenic degradation of polysaccharides and the characterization of polysaccharolytic clostridia from anoxic rice field soil. Syst Appl Microbiol 21, 185-200.
Chin, K.-J., Hahn, D., Hengtsmann, U., Liesack, W. \& Janssen, P. H. (1999). Characterization and identification of numerically abundant culturable bacteria from the anoxic bulk soil of rice paddy microcosms. Appl Environ Microbiol 65, 5042-5049.

Hedlund, B. P., Gosink, J. J. \& Staley, J. T. (1997). Verrucomicrobia div. nov., a new division of the Bacteria containing three new species of Prosthecobacter. Antonie Leeuwenhoek 72, 29-38.

Hengstmann, U., Chin, K.-J., Janssen, P. H. \& Liesack, W. (1999). Comparative phylogenetic assignment of environmental sequences of genes encoding $16 \mathrm{~S}$ rRNA and numerically abundant culturable bacteria from an anoxic rice paddy soil. Appl Environ Microbiol 65, 5050-5058.

Hugenholtz, P., Goebel, B. M. \& Pace, N. R. (1998). Impact of culture-independent studies on the emerging phylogenetic view of bacterial diversity. $J$ Bacteriol 180, 4765-4774.

Janssen, P. H., Liesack, W., Kluge, C., Seeliger, S., Schink, B. \& Harfoot, C. G. (1996). Sodium-dependent succinate decarboxylation by a new anaerobic bacterium belonging to the genus Peptostreptococcus. Antonie Leeuwenhoek 70, 11-20.

Janssen, P. H., Schuhmann, A., Mörschel, E. \& Rainey, F. A. (1997). Novel anaerobic ultramicrobacteria belonging to the Verrucomicrobiales lineage of bacterial descent isolated by dilution culture from anoxic rice paddy soil. Appl Environ Microbiol 63, $1382-1388$.

Jukes, T. H. \& Cantor, C. R. (1969). Evolution of protein molecules. In Mammalian Protein Metabolism, vol. 3, pp. 21-132. Edited by H. N. Munro. New York: Academic Press.

O'Farrell, K. A. \& Janssen, P. H. (1999). Detection of verrucomicrobia in a pasture soil by PCR-mediated amplification of 16S rRNA genes. Appl Environ Microbiol 65, 4280-4284.

Petroni, G., Spring, S., Schleifer, K.-H., Verni, F. \& Rosati, G. (2000). Defensive extrusive ectosymbionts of Euplotidium (Ciliophora) that contain microtubule-like structures are bacteria related to Verrucomicrobia. Proc Natl Acad Sci U S A 97, 1813-1817.

Saitou, N. \& Nei, M. (1987). The neighbor-joining method: a new method for reconstructing phylogenetic trees. Mol Biol Evol 4, 406-425.

Schlesner, H. (1987). Verrucomicrobium spinosum gen. nov., sp. nov.; a fimbriated prosthecate bacterium. Syst Appl Microbiol 10, 54-56.

Staley, J. T., de Bont, J. A. M. \& de Jonge, K. (1976). Prosthecobacter fusiformis nov. gen. et sp., the fusiform caulobacter. Antonie Leeuwenhoek 42, 333-342.

Vandekerckhove, T. T. M., Willems, A., Gillis, M. \& Coomans, A. (2000). Occurrence of novel verrucomicrobial species, endosymbiotic and associated with parthenogenesis in Xiphinema americanum-group species (Nematoda, Longidoridae). Int $J$ Syst Evol Microbiol 50, 2197-2205.

Zwart, G., Hiorns, W. D., Methè, B. A., van Agterveld, M. P., Huismans, R., Nold, S. C., Zehr, J. P. \& Laanbroek, H. J. (1998). Nearly identical $16 \mathrm{~S}$ rRNA sequences recovered from lakes in North America and Europe indicate the existence of clades of globally distributed freshwater bacteria. Syst Appl Microbiol 21, 546-556. 